д-ра пед. наук : 13.00.02/ Криловець Микола Григорович. - Київ, 2009. - 482 с. 4. Регіональна економічніа і соціальна географія світу: [навчальна програма для студентів напряму підготовки 6.040104. Географія]/ уклад. В. Бурман. - Кривий Ріг: КПІ ДВНЗ «КНУ», 2012. - 20 с. 5. Тімець О. В. Формування фахової компетентності майбутнього вчителя географії у процесі професійної підготовки / О.В.Тімець / Уманський державний педагогічний університет ім. Павла Тичини. - Умань : Сочінський, 2010. - 340 с. 6. Шуканова А. А. Функціональна структура професійної компетентності вчителя географії в системі неперервної освіти [Електронний ресурс] / А. А. Шуканова. - Режим доступу : http://undip.org.ua/upload/iblock/ d23/5_12.pdf (дата звернення: 17.11.2015).

УДК 348.147:519.85.007.2

Ганна Горикова

\title{
НАВЧАННЯ МАЙБУТНІХ ІНЖЕНЕРІВ-МЕТАЛУРГІВ МАТЕМАТИЧНОГО МОДЕЛЮВАННЯ У ПРОЦЕСІ РОЗВ'ЯЗУВАННЯ ПРОФЕСІЙНО СПРЯМОВАНИХ ЗАДАЧ
}

Горшкова Г. А. Навчання майбутніх інженерів-металургів математичного моделювання у процесі розв’язування професійно спрямованих задач.

У статті розглядаються можливості застосування математичного моделювання у процесі професійної підготовки майбутніх інженерів-металургів. Підкреслено, що упровадження нових технологій у розроблення і функціонування металургійного комплексу значно підвищує вимоги в галузі фундаментальних наук до випускників вищих навчальних закладів інженерного профілю.

Ключові слова: математичне моделювання, модель, технологічний процес, майбутній інженер-металург, вища математика.

Горшкова А. А. Обучение будущих инженеров-металлургов математическому моделированию в процессе решения профессионально направленных задач.

В статье рассматривается возможность применения математического моделирования в процессе профессиональной подготовки будущих инженеров-металлургов. Подчеркнуто, что внедрение новых технологий в разработку и функционирование металлургического комплекса значительно повышает требования в области фундаментальных наук к выпускникам высших учебных заведений инженерного профиля.

Ключевые слова: математическое моделирование, модель, технологический процесс, будущий инженер-металлург, высшая математика.

Gorshkova H. A. Mathematical modeling training of future metallurgical engineers in the process of professionally oriented problems solution.

This article examines the possibility of using mathematical modeling in the process of future metallurgical engineers training. It was emphasized that the introduction of new technologies in the development and operation of the metallurgical complex significantly increases the demands in the field of basic sciences for university graduates of engineering profile.

Key words: mathematical modeling, model, process, future metallurgical engineer, higher mathematics.

Упровадження нових наукомістких технологій у процес розроблення i 
функціонування металургійного комплексу значно підвищує вимоги в галузі фундаментальних наук до випускників вищих навчальних закладів інженерного профілю. Майбутні інженери-металурги повинні мати глибокі професійні знання та уміння, володіти математичними методами і застосовувати їх у практичній діяльності. Як навчальний предмет вища математика дозволяє не тільки своїми методами і засобами виявляти зв'язки реальних явищ і процесів у виробничій діяльності, а й формувати навички майбутніх інженерів у математичному дослідженні прикладних питань; уміння будувати й аналізувати математичні моделі інженерних завдань.

Математична освіта посідає особливе місце в національній моделі освіти. Вона розвиває інтелектуальні здібності людини, формує вміння проводити аналогії, логічно обгрунтовувати власну думку, творчо застосовувати здобуті знання. Математика $є$ мовою інженерних досліджень. Досконале володіння математичною мовою передбачає вміння переходити від конкретно поставленої практичної задачі до іï абстрактної математичної моделі.

Проблема навчання математики у вищій школі знайшла відображення в багатьох наукових дослідженнях, зокрема, наукові основи навчання математики студентів нематематичних спеціальностей розкрито в працях Т. Крилової, теорія і методика загальнонаукової підготовки в інженерній вищій школі розглянуто в дослідженнях Е. Лузік. Питанню застосування методу моделювання у процесі фундаментальної підготовки присвячено праці Н. Буланової, А. Верланя, М. Жалдака, О. Михайлова, С. Семерікова, В. Хозієва. Дослідженням проблеми професійної підготовки майбутніх фахівців, зокрема таким їі аспектам, як теоретичні та методичні засади професійної підготовки майбутніх фахівців у вищій школі займалися А. Алексюк, М. Євтух, А. Кузьмінський та ін.

Метою статті є з'ясування сутності математичного моделювання та необхідність застосування цього методу у змісті підготовки майбутніх інженерів металургійної галузі.

Моделювання - відтворення характеристик певного об’єкта на іншому об'єкті, спеціально створеному для його вивчення. Останній об’єкт називається моделлю.

У науковій та науково-методичній літературі запропоновано велику кількість виначень моделі, але жодне з них повною мірою не відображає сутність цього поняття.

За М. Власовим, «модель»- це логічний або математичний опис компонентів та функцій, які визначають суттєві властивості об’єкта, що моделюється, або процесу. Модель використовують як умовний образ, сконструйований для спрощення дослідження [2].

На думку I. Теплицького, «модель»- це такий матеріальний об'єкт або мислено уявлювальний об’єкт, який у процесі пізнання (вивчення) замінює собою реальний об'єкторигінал, і при цьому зберігає деякі важливі для певного дослідження риси оригіналу [5].

У своїй книзі «Моделювання та філософія» В. Штофф надає означення моделі як уявно зображеної або матеріально реалізованої системи, яка відображає та відтворює об’єкт так, що її вивчення надає нову інформацію про нього [8].

За В. Вітлінським під моделлю можна розуміти образ реального об’єкта (процесу) в матеріальній чи ідеальній формі (тобто такий, який описано знаковими засобами певною мовою), що відображає суттєві властивості модельованого об’єкта (процесу) і заміщує його у ході дослідження й управління [1].

На думку П. Ейкхофа, «модель»- це зображення суттєвих сторін реальної системи, яке в зручній формі відображає інформацію про систему [9].

I. Новик під моделюванням розуміє метод практичного або теоретичного опосередкованого оперування об’єктом, у ході якого безпосередньо досліджується не сам 
об’єкт, а деяка проміжна система - модель, яка:

а) перебуває в деякій об’єктивній відповідності із самим об’єктом пізнання;

б) може в процесі пізнання на його відомих етапах заміщувати в певних взаємозв'язках сам виучуваний об'єкт;

в) здатна надавати у процесі її дослідження нову інформацію про самий об’єкт.

Модель може виступати як у вигляді речовинного об’єкта, так і у вигляді деякого сполучення знаків [3].

Ми погоджуємося $з$ висновком, який у своєму дослідженні робить Н. Хараджян: «модель» $\epsilon$ специфічною, якісно своєрідною формою, i, одночасно засобом наукового пізнання, а «моделювання» - це процес, що є особливою формою опосередкування, коли дослідник ставить між собою і об’єктом, що його цікавить, деяку проміжну ланку модель [10].

Роль моделювання в сучасній науці настільки $є$ значною, що воно стало одним 3 основних інструментів наукового пізнання i знайшло широке застосування під час дослідження металургійних процесів і управлінні ними.

Для металургії як галузі господарювання характерні дві особливості. По-перше, масштаби виробництва металів і сплавів вивели металургію по споживанню енергетичних ресурсів на одне з перших місць серед інших галузей. По-друге, технологічні процеси в металургії, які пов'язані з переробленням сировини й одержанням кінцевих продуктів, мають перебіг в умовах підвищених температур. Інженерові-металургові доводиться розв'язувати широке коло завдань - від підготовки шихти, виплавки металу, одержання якісної готової продукції до вирішення екологічних проблем зниження рівня теплового та хімічного забруднення навколишнього середовища [6]. Тому математичне моделювання в металургії дозволяє швидко знаходити оптимальні розв'язки зазначених завдань, допомагає за планування виробництва та керування ним.

В. Цимбал, досліджуючи умови застосування математичного моделювання металургійних процесів, підкреслював, що «моделювання»- це такий різновид наукового дослідження різних явищ у природі й техніці, коли досліджуваний реальний об'єкт (технологічний процес, обладнання, де він здійснюється, або речовина) замінюється його моделлю. При цьому модель повинна володіти певною сукупністю найважливіших для певного дослідження властивостей, аналогічних властивостям досліджуваного об'єкта. Результати моделювання використовуються в подальшому дослідженні об'єкта, проектуванні нових або модернізації наявних технологій, оптимізації схемо-конструктивних рішень у галузі удосконалення структури і режимів роботи обладнання, оптимальному плануванні виробництва й автоматизованому управлінні технологічними процесами.

Із розвитком системних досліджень і розширенням експериментальних методів вивчення реальних об’єктів великого значення набувають математичні методи аналізу й синтезу. Подібність та моделювання дозволяють по-новому описати реальний процес і спростити його експериментальне вивчення.

Моделювання грунтується на деякій аналогії реального та мисленевого експерименту (наприклад, виявлення впливу зміни хімічного складу шихти на техніко-економічні показники (ТЕП) процесу плавки). Для пояснення реальних процесів висуваються гіпотези, задля їх підтвердження проводиться експеримент, тобто певна процедура організації та спостерігання явищ, яку здійснюють в умовах, близьких до реальних або тих, що імітують [7].

Аналіз змістового складника дисциплін предметно-професійної підготовки майбутніх 
інженерів-металургів дозволив виокремити основні математичні поняття, які найчастіше $\epsilon$ математичними моделями реальних технологічних процесів у металургії. Зокрема, математичною моделлю технологічного об’єкта управління є функція багатьох змінних.

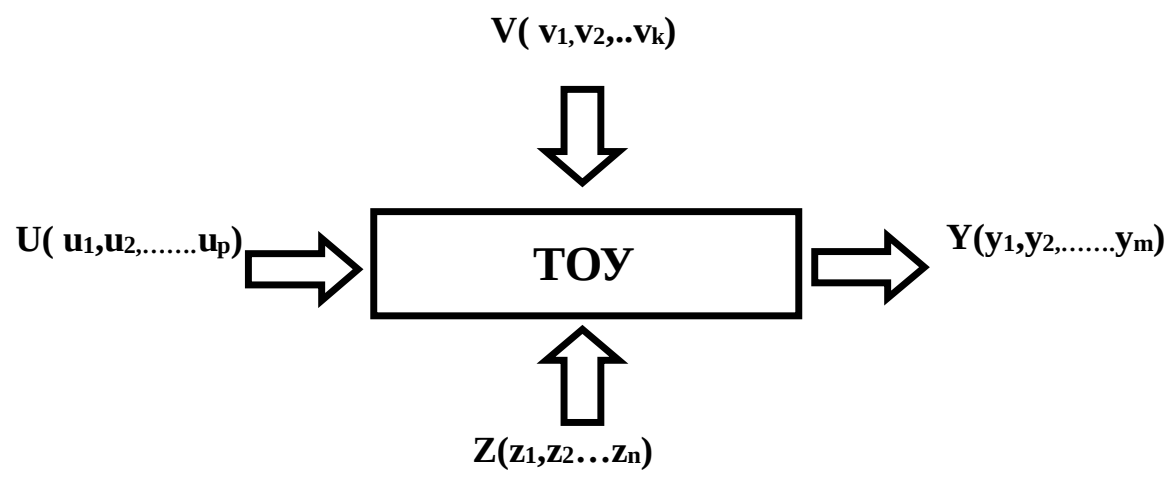

Рис. 1. Схема технологічного об’єкта управління (ТОУ)

На рис. 1 показано схему технологічного об’єкта управління (ТОУ), де U - вектор контрольованих вхідних даних (витрати сировини, енергії, палива тощо); V- вектор контрольованих збурювань (якісні показники сировини, параметри стану устаткування тощо); Z - вектор неконтрольованих збурювань; Y - вектор вихідних даних [показники стану технологічного процесу (температура, тиск, склад речовини), якісні кількісні показники проміжних (ливарна форма) або кінцевих (виливок) продуктів, техніко-економічних показників виробництва].

Сукупність математичних рівнянь, що відображають залежність вихідних величин від вхідних, доповнені обмеженнями, які накладаються на ці величини, вимогами безпеки функціонування, рівняннями зв’язку з іншими об’єктами і є математична модель процесу.

Модель процесу доповнюється алгоритмом керування, що забезпечує випуск продукції із заданими показниками незалежно від деякого коливання характеристик вихідних матеріалів.

Математична модель оптимального керування технологічним процесом ливарного виробництва включає цільову функцію. В основі цільової функції можуть бути різні технікоекономічні критерії, наприклад, мінімальний час регулювання, обмеження на температурні градієнти при відливанні, що викликає її розтріскування у процесі кристалізації, мінімальна собівартість одержання відливки тощо.

Завдання оптимального керування виробництвом загалом поділяють на підзадачі: шихтовка; плавка; сумішприготування; формування; розливання; охорона навколишнього середовища [6].

Поряд 3 функцією багатьох змінних широкого застосування набули диференціальні рівняння та їх системи. Якщо основні змінні процесу змінюються у часі і у просторі, то моделі записуються у вигляді диференціальних рівнянь у частинних похідних. Якщо основні змінні процесу не змінюються у просторі, а змінюються тільки в часі, то математичні моделі, що описують такі процеси, записуються у вигляді звичайних диференціальних рівнянь.

Розглянемо приклад. Ентропія становить чинник екстенсивності тепловіддачі. Ця термодинамічна функція має велике значення при розв’язуванні багатьох практичних задач, які стоять перед інженером-металургом, пов'язаних переважно з вивченням рівноваги у процесі.

Нехай іде хімічна реакція розкладання речовини А, у результаті якої утворюється 
речовина В. Експериментально встановлено, що вона має перший порядок концентрації С А, а значення константи швидкості для умов ії̈ здійснення дорівнює k.

Швидкість реакції дорівнює $\mathrm{r}_{\mathrm{a}}=-\mathrm{k} \mathrm{C}_{\mathrm{a}}$, або $\frac{d c_{a}}{d t}=-k c_{a}$.

Визначимо початкові умови для розв’язку диференціального рівняння кінетики. Будемо вважати, що в початковий момент реакції нам відома концентрація речовини а,

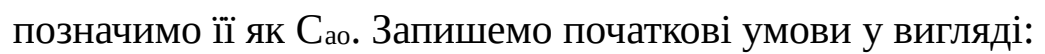

$$
\left[t=0 ; C_{A}=C_{A 0}\right] \text {. }
$$

Проінтегруємо отримане рівняння, використовуючи визначений інтеграл. Межі інтегрування визначаються з початкових умов: коли час дорівнює нулю, концентрація А дорівнює початковому значенню СА, у довільний момент $t$ концентрація дорівнює $C_{A}: \int_{C_{A 0}}^{C_{A}} \frac{d C_{A}}{C_{A}}=-k \int_{0}^{t} d t$

У результаті інтегрування маємо:

$$
\ln C_{A}-\ln C_{A 0}=-k t \text {, }
$$

замінемо різницю логарифмів логарифмом частки:

$$
\ln \frac{C_{A}}{C_{A 0}}=-k t \text {, після потенціювання одержимо: } \frac{C_{A}}{C_{A 0}}=e^{-k t} \text {. }
$$

Після всіх перетворень розв'язок диференціального рівняння представляє собою показникову спадну функцію: $C_{A}=C_{A 0} \cdot e^{-k t}$.

Перевіримо, чи не суперечить отриманий розв’язок умовам нашого завдання. При $t=0$, тобто в момент початку хімічної реакції $C_{A}=C A_{0}$, оскільки експонента наближається до одиниці. Дійсно, у початковий момент концентрація речовини А дорівнює Со. При $t \rightarrow \infty$ експонента 3 від'ємним показником наближається за величиною до нуля. За нескінченно великий час унаслідок хімічної реакції вся речовина А розкладається і утворюється речовина В.

Математичне описання відтворює найбільш суттєві сторони процесу. Тому, варіюючи окремі параметри, можна одержувати відомості про вплив цих варіацій на показники процесу. Так можна змінювати параметри технологічного режиму (температуру, тиск, склад, швидкість руху матеріальних потоків тощо) й одержувати відомості про їхній вплив на перебіг процесу.

Отже, для того щоб досліджувати, оптимізовувати, удосконалювати технологію процесів управління металургійним виробництвом на заняттях з вищої математики, потрібно добитися гарного засвоєння студентами основних знань і методів 3 тем «Функція багатьох змінних», «Диференціальне та інтегральне числення», «Диференціальні рівняння» тощо. Вища математика належить до блоку фундаментальних дисциплін, знання яких є опорою для усвідомленого засвоєння професійно-орієнтованих дисциплін (технічна механіка, опір матеріалів, автоматизація виробничих процесів, теплотехніка, фізична хімія тощо), які, у свою чергу, надають майбутньому інженеру-металургу можливість вільно орієнтуватися у вивченні спеціальних дисциплін: теорія металургійних процесів, теорія та технологія виробництва металів, матеріалознавство та оброблення металів, металургійні печі.

У статті означено поняття «математична модель», обгрунтовано, що моделювання $є$ ефективним та універсальним методом наукового пізнання; надає змогу, зокрема, інженеру- 
металургу експериментувати з об’єктами в тих випадках, коли робити це на реальному об’єкті практично неможливо або недоцільно; показано ефективність використання математичного моделювання у професійній підготовці інженерів-металургів.

\section{Література}

1. Вітлінський В. В. Моделювання економіки: [навч. посіб.] / В. В. Вітлінський. Київ : КНЕУ, 2003. - 408 с. 2. Власов М. П. Моделирование экономических процессов / М. П. Власов, П. Д. Шимко. - Ростов на Дону : Феникс, 2005. - 409 с. З. Дворецкий С. И. Компьютерное моделирование и оптимизация технологических процессов и оборудования : [учеб. пособ.] / С. И. Дворецкий, А. Ф. Егоров , Д. С. Дворецкий. - Тамбов : ТГТУ, 2003. 224 с. 4. Горенский Б. М. Моделирование процессов и объектов в металлургии : конспект лекций [Электронный ресурс]/ $\quad$ Б. М. Горенский, Л. А. Лапина, А. Ш. Любанова. Красноярск : ИПК СФУ, 2008. - 97 с. - Режим доступа : http://icmim.sfu-kras.ru/sites/icm. institute.sfu-kras.ru/ files/u_lab_0.pdf (дата звернення: 05.03.2014). 5. Теплицький I. О. Елементи комп’ютерного моделювання : [навч. посіб.] / І. О. Теплицький. - Кривий Ріг : КДПУ, 2010. - 230 с. 6. Цаплин А. И. Моделирование теплофизических процессов и объектов в металлургии : [учеб. пособ.] / А. И. Цаплин, И. Л. Никулин. - Пермь : ПГТУ, 2011. - 299 с. 7. Цимбал В. П. Математическое моделирование металлургических процессов : $\quad$ [учеб. пособ.] / $\quad$ В. П. Цимбал. - Москва : Металлургия,1986. - 240 с. 8. Штофф В. А. Моделирование и философия / В. А. Штофф. - Москва : Наука, 1966. 310 с. 9. Эйкхоф П. Основы идентификации систем управления / П. Эйкхоф. - Москва : Мир, 1975 - 236 с. 9. Хараджян Н. А. Педагогічні умови підготовки фахівців з економічної кібернетики засобами комп’ютерного моделювання: дис. на здобуття наук. ступеня канд. пед. наук : 13.00.04 / Хараджян Наталя Анатоліївна. - Черкаси, 2010. - 287 с.

Сергій Зелінський

\section{СИСТЕМА КОМП'ЮТЕРНОЇ МАТЕМАТИКИ ЯК ЗАСІБ ФОРМУВАННЯ КОМПЕТЕНТНОСТІ В МОДЕЛЮВАННІ МАЙБУТНІХ ІНЖЕНЕРІВ}

Зелінський С. С. Система комп’ютерної математики як засіб формування компетентності в моделюванні майбутніх інженерів.

У статті розглядається система комп’ютерної математики (Maple) як засіб формування компетентності в моделюванні майбутніх інженерів. Детально розглянуто поняття системи комп’ютерної математики та визначено характеристики цього поняття. Наведено можливості системи комп’ютерної математики в процесі підготовки майбутніх інженерів. Розглянуто практичні аспекти застосування системи комп’ютерної математики.

Ключові слова: система комп’ютерної математики, компетентність в моделюванні, майбутні інженери, навчальний процес, професійні задачі.

Зелинский С. С. Система компьютерной математики как средство формирования компетентности в моделировании будущих инженеров.

В статье рассматривается система компьютерной математики (Maple) как способ формирования компетентности в моделировании будущих инженеров. Детально рассмотрено понятие системы компьютерной математики и определены характеристики данного понятия. Приведены возможности системы компьютерной математики в процессе подготовки 